Research Article

\title{
Determination of the Gene Polymorphisms of Tumor Necrosis Factor-Alpha and Interleukin- 10 in Coronary Artery Disease Patients in Iraq
}

\author{
Abbas Ali Menshed ${ }^{1}$, Hasan R. Khudhur², Luma Hakem $\mathrm{Ali}^{3}$ \\ ${ }^{1}$ Ministry of Education, Directorate of Education Muthanna, Iraq. \\ ${ }^{2}$ AL-Muthanna University, Iraq. \\ ${ }^{3}$ Ministry of Education, Iraq. \\ Corresponding author. E-mail: Abbas0780755@gmail.com
}

Received: Apr. 17, 2020; Accepted: May 14, 2020; Published: Jun. 28, 2020

Citation: Abbas Ali Menshed, Hasan R. Khudhur, and Luma Hakem Ali, Determination of the Gene Polymorphisms of Tumor Necrosis FactorAlpha and Interleukin-10 in Coronary Artery Disease Patients in Iraq. Nano Biomed. Eng., 2020, I2(2): I78-183. DOI: $10.5101 /$ nbe.v12i2.p178-183.

\begin{abstract}
Coronary artery disease (CAD) is a widespread kind of cardiovascular disease and is a usual reason of heart attacks, including stable and unstable angina pectoris and myocardial infarctions. We designed this study to examine a probable correlation Interleukin-10 (-1082G/A) and tumor necrosis factor- $\alpha$ (G-308A) gene polymorphism and the coronary artery disease in the Iraqi population. The subjects enrolled in this study were categorized into 2 groups: Group one (140 subjects of CAD), and group two (95 healthy controls). There was no significant correlation between A allele and A/A genotype of TNF- $\alpha$ G-308A, and coronary artery disease patients $(p$-value $=0.715$ and $p$-value $=0.762$ respectively), while there was important correlation between $\mathrm{G}$ allele and G/G genotype of IL-10 $(\mathrm{G}-1082 \mathrm{~A})$, and coronary artery disease patients ( $\mathrm{p}$-value $=0.005$ and $\mathrm{p}$-value $=0.039$ respectively). This study indicates that IL-10 G-1082A and TNF- $\alpha$ G-308A gene polymorphism may be considered a risk reason for coronary artery disease in Iraqis.
\end{abstract}

Keywords: Coronary artery disease; TNF- $\alpha$; Interleukin-10; Genotype; Allele; RFLP

\section{Introduction}

Cardiovascular disorders are the very common factors of disabilities and early mortality worldwide. Coronary artery disease (atherosclerosis) is serious kind of cardiovascular disease and is a main cause of heart problems [1], including stable and unstable angina pectoris, and myocardial infarction [2]. Different factors such as arterial hypertension, smoking, physical activity, hypertension, diabetes and blood cholesterol lead to the development of atherosclerosis [3]. The inflammatory response plays an important role throughout the various stages of atherosclerosis [4]. Formation of the foam cells results from amassing of macrophages loaded with cholesterol in the arterial wall. Its importance appears by their involvement in each step of atherosclerosis and by its prompt and severe thrombotic occurrence [5]. Death of foam cells will contribute to necrotic core formation, described as a depot of lipids and dead cells. However, some early schemes of the atherosclerosis cell biology conceived atherogenesis as a bland operation, without inflammatory cells being involved [6].

Macrophages are the common inflammatory cells in 
the plaque and produce different types of cytokines in the lesion surroundings, which can produce different pro- and anti- inflammatory cytokines such as TGF, IL1, IL-10, IL-12, IL-6, IL-18, IL-15, and TNF. Several studies have revealed that proinflammatory cytokines encourage the progress of atherosclerosis [7].

TNF- $\alpha$ is a proinflammatory cytokine and a potent immunomediator implicated a wide number of human diseases. Its absence from natural tissues and presence in the several of atherosclerotic lesion indicates its contribution to atherogenesis. TNF- $\alpha$ may involve in atherosclerosis by affecting the stimulation and synthesis of adhesion particles and by activation of chemoattractants, cytokines and growth factors. High concentration of TNF- $\alpha$ in a stable angina pectoris and unstable angina pectoris patients in comparison with control individuals [8]. Most possibly, cytokine gene polymorphism is one of the most important factors for this disease. Many studies were performed to evaluate influences of TNF- $\alpha$ gene polymorphism on cardiovascular disease susceptibility $[9,10]$. TNF- $\alpha$ gene expression is influenced by multiple single nucleotide polymorphisms, polymorphisms in areas $-238 \mathrm{G}<\mathrm{A}$ and $-308 \mathrm{G}<\mathrm{A}$ were significantly related to alterations in TNF- $\alpha$ gene activity [11].

Interleukin-10 is an anti-inflammatory cytokine. It prevents the function of macrophages, NK cells and Th1 cells during infection, every one of which is necessary for optimum pathogen clearance [12]. IL-10 gene is mapped at the intersection between 1q31 and 1q32 on chromosome 1 , and has 5 exons. It has many polymorphisms (IL-10592C/A, IL-10-819C/T and IL-10-1082G/A) in the promoter region, that is embroiled in modulating IL-10 gene expression, which could affect susceptibility of coronary artery disease [13]. IL-10 is found in human atherosclerotic plaques prematurely and later, and its expression is related with a low amount of inducible nitric oxide synthase (iNOS). IL-10 prevents several cellular operations that may play a major role in rupture, thrombosis, or plaque progression [14]. To the best of our knowledge there is no similar study in Iraq on the relation of IL-10-1082G/A and TNF- $\alpha-308 \mathrm{G} / \mathrm{A}$ gene polymorphisms with coronary artery disease.

\section{Experimental \\ Subject}

The subjects enrolled in this study were categorized into two groups: Group one (140 subjects of CAD), and group two (95 healthy controls). The patients attended Al-Hussein Teaching Hospital in AlMuthanna and Sadr Medical City in Najaf, Iraq, for the period from April 2019 to October 2019. A number of tests were used to to diagnose patients, including electrocardiogram, cardiac stress testing and coronary angiogram. Each patient's chart was reviewed to obtain the following: age, sex, family history.

\section{Genotyping}

PCR-RFLP technique was performed for detection of IL-10 and TNF- $\alpha$ genotypes in blood samples of CAD, as wells as in healthy control groups, by using specific primers (Table 1).

The AccuPower PCR PreMix Kit was used for detection of IL-10 and TNF- $\alpha$ genes. Restriction endonuclease enzyme (NcoI) was used in cutting of TNF- $\alpha$ gene, and XagI (EcoNI) restriction enzyme for IL-10. After that, REFLP-PCR product was analysis by $3 \%$ agarose gel electrophoresis methods and visualized by UV Transilluminator.

\section{Statistical analysis}

Statistical analyses were completed using SPSS version 24 computer software (statistical package for social sciences) in association with Microsoft Excel 2010. Determining the statistical differences among different groups and comparison of allelic and haplotype frequencies were made using the odds ratio with the $95 \%$ confidence. Comparison of gender frequency distributions between patients and control groups was achieve by using Fisher's exact test. The statistical significance was accepted as mean $\pm \mathrm{SD}$, and a $\mathrm{p}$-value of $\leq 0.05$.

Table 1 Sequences of primers and the PCR product size

\begin{tabular}{ccc}
\hline Primers & & Sequences \\
\hline TNF- $\alpha-308 G / A$ & P & 5 'AGGCAATAGGTTTTGAGGGCCAT3' \\
IL-10-1082G/A & R & 5'TCCTCCCTGCTCCGATTCCG3' \\
& R & 5' CCAAGACAACACTACTAAGGCTCCTTT3' \\
\hline
\end{tabular}




\section{Results and Discussion}

This case-control study included 235 individuals including 140 coronary artery disease patients (54.29\% male and $45.71 \%$ female) and 95 healthy controls (57.9\% male and $42.1 \%$ female). The mean age of controls and cases were $47.57 \pm 16.01$ and $49.07 \pm$ 16.83 years, respectively. The odds ratio was 0.863 (Table 2 and 3 ).

Table 2 The control-patient difference in mean age

\begin{tabular}{cccc}
\hline Age (years) & Control & Patient & P-value \\
\hline Range & $(24-68)$ & $(27-70)$ & \\
Mean & 47.57 & 49.07 & \\
SE & 1.64 & 1.42 & $0.49[\mathrm{NS}]$ \\
SD & 16.01 & 16.83 & \\
$\mathrm{~N}$ & 95 & 140 &
\end{tabular}

Note: $\mathrm{NS}=$ Not significant; $\mathrm{SE}=$ Standard error; $\mathrm{SD}=\mathrm{Standard}$ deviation.

For genotyping of IL-10 and TNF- $\alpha$, PCR-RFLP were used. There were 3 genotypes: For TNF- $\alpha$ G308A AA, GA and GG with band sizes 107 pb, 20/87/107 $\mathrm{pb}$ and $20 / 87 \mathrm{pb}$, respectively (Fig. 1); for IL-10
G1082A AA, GA and GG with band sizes 97/280 pb, 27/97/253/280 pb and 27/97/253 pb, respectively (Fig. 2 ). The genotype relative frequency of TNF- $\alpha$ was as follows: $53.57 \%(\mathrm{GG}), 32.86 \%(\mathrm{GA})$ and $13.57 \%$ (AA) in CAD patients, and 51.58\% (GG), 33.684\% (GA) and $14.736 \%$ (AA) in the control groups. On the other hand, genotype relative frequency of IL-10-1082G/ A was as follows: 46.43\% (GG), 26.43\% (GA) and $27.14 \%$ (AA) in CAD patients, and 62.1\% (GG), 20\% (GA) and $17.9 \%$ (AA) in the control subjects (Table 4 and 5). The present study was conducted to determine the relationship between the genotypes/allotypes of IL10 and TNF- $\alpha$ gene polymorphism in CAD patients and their clinical features.

\section{Distribution of IL-10, TNF-a alleles and genotypes in control and patient groups}

There was no significant association between CAD and polymorphism of TNF- $\alpha-308 \mathrm{G} / \mathrm{A}$. Statistical examination showed that TNF- $\alpha$ was not a risk aspect for CAD. There was no significant variation between the $\mathrm{G}$ and $\mathrm{A}$ alleles at -308 from control and patients with $\mathrm{CAD}(\mathrm{OR}=0.928 ; 95 \% \mathrm{CI}=0.623-1.383$; $\mathrm{p}$-value $=0.715)$.

The study results were constant with the study by Herman et al. [15] who investigated patients with

Table 3 Comparison of gender frequency between patient and control groups

\begin{tabular}{|c|c|c|c|c|c|c|}
\hline & \multicolumn{2}{|c|}{ Controls } & \multicolumn{2}{|c|}{ Patients } & \multirow[t]{2}{*}{ Odds ratio } & \multirow[t]{2}{*}{ P-value } \\
\hline Gender & N. & $\%$ & $\mathrm{~N}$. & $\%$ & & \\
\hline Males & 55 & 57.9 & 76 & 54.29 & \multirow{2}{*}{0.863} & \multirow{2}{*}{$\begin{array}{c}(0.58) \\
\text { Not significant at p-value }<0.05\end{array}$} \\
\hline Females & 40 & 42.1 & 64 & 45.71 & & \\
\hline Total & 95 & 100 & 140 & 100 & & \\
\hline
\end{tabular}

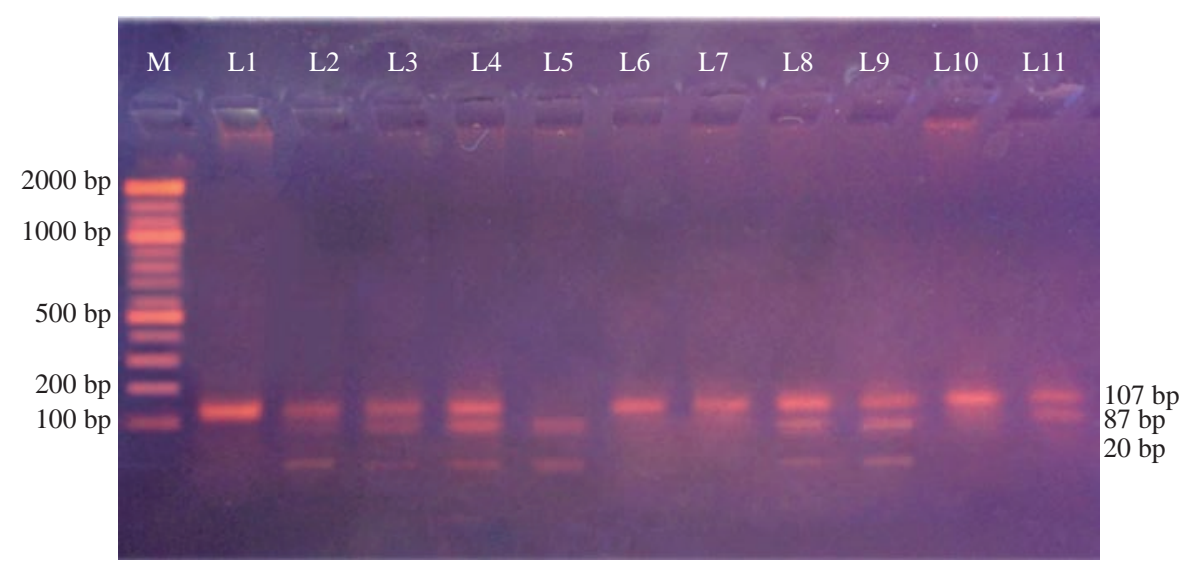

Fig. 1 TNF- $\alpha$-308G/A PCR products after digestion with Nco1 restriction enzyme. Lane 1, 6, 10: AA genotype (107 bp); Lane 2-4, 8, 9, 11: GA genotype (20/87/107 bp); Lane 5, 7: GG genotype (20,87 bp); Lane M: DNA molecular size marker (100 - 2000 bp). 


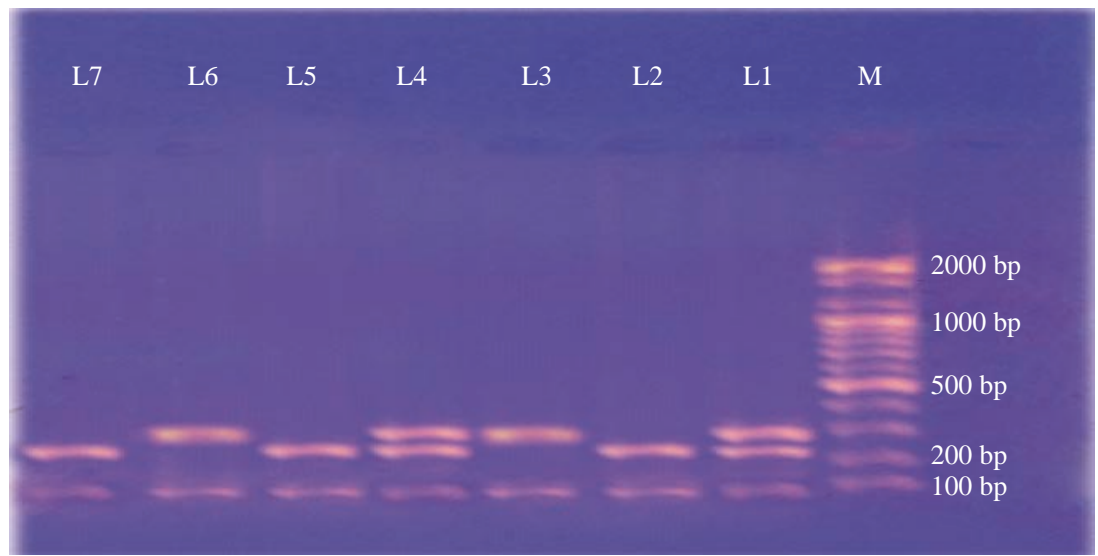

Fig. 2 IL-10-1082G/A PCR products after digestion with with Xag restriction enzyme I. Lane 3, 6: AA genotype (97/280 pb); Lane 1, 4: GA genotype (97/253/280 pb) (27 bp not shown); Lane 2, 5, 7: GG genotype (97/253 pb) (27 bp not shown); Lane M: DNA molecular size marker (100-2000 bp).

Table 4 Correlation between gene expression of TNF- $\alpha$ and CAD disease

\begin{tabular}{|c|c|c|c|c|c|c|c|c|c|}
\hline \multirow{2}{*}{ Genotype / Allele } & \multicolumn{2}{|c|}{$\begin{array}{l}\text { Patients } \\
(\mathrm{n}=140)\end{array}$} & \multicolumn{2}{|c|}{$\begin{array}{l}\text { Control } \\
(\mathrm{n}=95)\end{array}$} & \multirow{2}{*}{ P-value } & \multirow{2}{*}{ Odd ratio } & \multirow{2}{*}{$\begin{array}{c}\text { 95\% Confidence } \\
\text { interval }\end{array}$} & \multirow{2}{*}{$\mathrm{EF}$} & \multirow{2}{*}{$\mathrm{PF}$} \\
\hline & No. & $\%$ & No. & $\%$ & & & & & \\
\hline GG & 75 & 53.57 & 49 & 51.58 & 1 & 1 & $0.601-1.663$ & 0 & $* * *$ \\
\hline GA & 46 & 32.86 & 32 & 33.684 & 0.831 & 0.939 & $0.527-1.672$ & $* * *$ & 0.457 \\
\hline AA & 19 & 13.57 & 14 & 14.736 & 0.762 & 0.886 & $0.407-1.931$ & $* * *$ & 0.515 \\
\hline G & 196 & 70 & 130 & 68.42 & 1 & 1 & $0.730-1.368$ & 0 & $* * *$ \\
\hline A & 84 & 30 & 60 & 31.58 & 0.715 & 0.928 & $0.623-1.383$ & $* * *$ & 0.043 \\
\hline
\end{tabular}

Note: $\mathrm{PF}=$ Preventive fraction; $\mathrm{EF}=$ Etiology fraction.

Table 5 Correlation between gene expression of IL-10 and CAD disease

\begin{tabular}{|c|c|c|c|c|c|c|c|c|c|}
\hline \multirow{2}{*}{ Genotype / Allele } & \multicolumn{2}{|c|}{$\begin{array}{l}\text { Patients } \\
(\mathrm{n}=140)\end{array}$} & \multicolumn{2}{|c|}{$\begin{array}{l}\text { Control } \\
(\mathrm{n}=95)\end{array}$} & \multirow{2}{*}{ P-value } & \multirow{2}{*}{ Odd ratio } & \multirow{2}{*}{$\begin{array}{c}95 \% \text { Confidence } \\
\text { interval }\end{array}$} & \multirow{2}{*}{$\mathrm{EF}$} & \multirow{2}{*}{$\mathrm{PF}$} \\
\hline & No. & $\%$ & No. & $\%$ & & & & & \\
\hline AA & 38 & 27.14 & 17 & 17.9 & 1 & 1 & $0.445-2.245$ & 0 & $* * *$ \\
\hline GA & 37 & 26.43 & 19 & 20 & 0.734 & 0.871 & $0.393-1.930$ & $* * *$ & 0.088 \\
\hline GG & 65 & 46.43 & 59 & 62.1 & $0.039 *$ & 0.492 & $0.251-0964$ & $* * *$ & 0.351 \\
\hline A & 113 & 40.36 & 53 & 27.9 & 1 & 1 & $0.630-1.586$ & 0 & $* * *$ \\
\hline G & 167 & 59.64 & 137 & 72.1 & $0.005^{*}$ & 0.571 & $0.384-0.850$ & $* * *$ & 0.292 \\
\hline
\end{tabular}

Note: $\mathrm{PF}=$ Preventive fraction; $\mathrm{EF}=$ Etiology fraction; * statistically significant.

coronary heart disease and found no association between polymorphisms in TNF- $\alpha$ and susceptibility to the disease. The frequencies of TNF- $\alpha-308 \mathrm{~A}$ and $-238 \mathrm{~A}$ in patients with CAD undergoing CABG did not differ significantly from those in controls. Koch et al. [8] also revealed there was no relationship between the TNF$\alpha-308 \mathrm{G} / \mathrm{A}$ promoter polymorphism and susceptibility to CAD. Another study found no evidence to support the theory that the presence of the 308A allele at the G-308A polymorphism of the TNF- $\alpha$ gene variation in CHD was related to an increased risk of CHD among the Chinese Han population [16]. There was no significant variation in the allele frequencies of TNF- $\alpha$ (G-308A) gene polymorphisms (19\% versus 19.6\%; p-value $=0.73$ ) between control subjects and CAD patients, respectively [17]. In India, a study done 
by Banerjee et al. [18] showed a single nucleotide polymorphism of TNF- $\alpha$ G-308A had no important correlation with coronary artery disease.

Conversely, in Iran, the study done by Somayyeh et al. [19] revealed there was an association between the TNF- $\alpha$ G-308A gene polymorphisms with the risk of atherosclerosis ( $\mathrm{p}$-value $<0.05$ ). Vendrell et al. [20] revealed that polymorphisms of TNF- $\alpha \mathrm{G}-308 \mathrm{~A}$ related with higher risk of CAD in Europe. In another study, Szalai et al. [21] showed individuals carrying the A allele of TNF- $\alpha$ G-308A exhibited an important association with susceptibility to CAD. The TNF- $\alpha$ 308G/A AA + GA genotypes were significantly higher in the control than in the patients ( $\mathrm{p}$-value $=0.004$ ). The allelic distribution for TNF- $\alpha-308 \mathrm{G} / \mathrm{A}$ was $11.3 \%$ in controls versus $20.3 \%$ in patients, a significant difference between the $\mathrm{G}$ and $\mathrm{A}$ alleles from the controls and patients $(\mathrm{OR}=1.9 ; 95 \% \mathrm{CI}=1.26-3.14$; $\mathrm{p}$-value $=0.003)[22]$.

The current analysis of genotype frequencies for IL10 polymorphism G-1082A revealed that G/G genotype and $\mathrm{G}$ allele played a significant role in increasing the CAD susceptibility $(\mathrm{OR}=0.49 ; 95 \% \mathrm{CI}=0.251-0.964$; $\mathrm{p}$-value $=0.03)$ and $(\mathrm{OR}=0.571 ; 95 \% \mathrm{CI}=0.384$ $0.850 ; \mathrm{p}$-value $=0.005)$, respectively.

The results of the current study agreed with the study done by Afzal et al. [23] who revealed significant variation between Pakistani CAD patient groups and a control group in SNP of IL-10 gene promoter at position 1082. In addition, Zahra Mousavi et al. [24] reported there was a significant relationship between CAD and IL-10 (G-1082A) G/G genotype and G allele ( $\mathrm{p}$-value $=0.020$ and $\mathrm{p}$-value $=0.017$, respectively $)$. Bown et al. [25] found that the A allele in SNP of IL10 G-1082A was related with an rising susceptibility for CAD in Caucasian (UK) patients. The frequency distribution of A allele and AA genotype of IL-10 G-1082A were significantly higher in coronary artery disease patients than controls [26].

On the contrary, a study done by Ben-hadjKhalifa et al. [27] showed IL-10 G-1082A gene polymorphisms was not a risk factor for CAD. There was not difference in the genotype frequencies of IL10 G-1082A polymorphisms between CAD patients (AA: $10.6 \%$, GA: $51.1 \%$, and GG: $38.3 \%$ ) and controls (AA: $13.8 \%$, GA: 43.1\%, and GG: 43.1\%) (p-value = 0.57 ) [28]. Another study found no association between CAD and IL-10-1082G/A, IL-10-592C/A, IL-10-819C/ $\mathrm{T}$ and IFN- $\gamma-874 \mathrm{~T} / \mathrm{A}$ polymorphisms [29].

\section{Conclusions}

TNF- $\alpha-308 \mathrm{G} / \mathrm{A}$ gene polymorphism was not a risk factor for $\mathrm{CAD}$ in Iraqi population. The important role of IL-10-1082G/A gene polymorphisms with regard to $\mathrm{G} / \mathrm{G}$ genotype and $\mathrm{G}$ allele and the pathogenesis of CAD in Iraqi population was discovered. Coronary artery disease has been widely spreading in the Iraqi population. Hence, it is recommended to the health institution that prescreen should be conducted for the genes of these cytokines which can be a predictive marker of CAD patients in Iraq.

\section{Acknowledgements}

I thank Al-Hussein Teaching Hospital in AlMuthanna and Sadr Medical City in Najaf, for all that they offered for the purpose of my study.

\section{Conflict of Interests}

The authors declare that no competing interest exists.

\section{References}

[1] D.P. Jones, J. Patel, Therapeutic approaches targeting inflammation in cardiovascular disorders. Biology, 2018, 7(4): 49.

[2] F. Hansen, H. Leif, Treatment with verapamil and trandolapril in patients with congestive heart failure and angina pectoris or myocardial infarction. American Heart Journal, 1997, 134:48-52.

[3] S. Ramanujam, Study of coronary artery in cadaver hearts: Morphological aspects. International Journal of Medical and Health Research, 2017, 3(2): 206-208.

[4] R. Ross, Atherosclerosis - an inflammatory disease. New England Journal of Medicine, 1999, 340: 115-126.

[5] X. Han, W.A. Boisvert, Interleukin-10 protects against atherosclerosis by modulating multiple atherogenic macrophage function. Thromb Haemost, 2015, 113: 505512.

[6] P. Libby, Inflammation in atherosclerosis. Arteriosclerosis Thrombosis Vascular Biolology, 2012, 32: 2045-2051.

[7] P.J. Little, A. Chait, and A. Bobik, Cellular and cytokinebased inflammatory processes as novel therapeutic targets for the prevention and treatment of atherosclerosis. Pharmacology and Therapeutics, 2011, 131: 255-268.

[8] K.B. Koch, Interleukin-10 and tumor necrosis factor gene polymorphisms and risk of coronary artery disease and myocardial infarction. Atherosclerosis, 2001, 159: 137144.

[9] W. Kaluza, S. Grossmann, R. Hug, et al., Different transcriptional activity and in vitro TNF- $\alpha$ production in psoriasis patients carrying the TNF- $\alpha$ 238A promoter polymorphism. Journal of Investigative Dermatology, 2000, 114(6): 1180-1183.

[10] R.B. Singh, S.A. Mengi, A.S. Arneja, et al., Pathogenesis of atherosclerosis: A multifactorial process. Experimental 
Clinical Cardiology, 2002, 7(1): 40-53.

[11] J. Bayley, C. Verweij, et al., Is there a future for TNF promoter polymorphisms? Genes and Immunity Journal, 2004, 5: 315-329.

[12] N. Kevin, G. Daniel, IL-10: The Master Regulator of Immunity to Infection. The Journal of Immunology, 2008, 180: 5771-5777.

[13] J.M. Fragoso, M. Vallejo, E. Alvarez-Leon, et al., Alleles and haplotypes of the interleukin 10 gene polymorphisms are associated with risk of developing acute coronary syndrome in Mexican patients. Cytokine, 2011, 55: 29-33.

[14] Z. Mallat, S. Besnard, Protective Role of Interleukin-10 in Atherosclerosis. Circulation Research, 1999, 85: 17-24.

[15] S.M. Herrmann, V. Nicaud, C. Mallet, et al., Polymorphisms of the tumour necrosis factor-alpha gene, coronary heart disease. European Journal of Clinical Investigation, 1998, 28(1): 59-66.

[16] H. Chu, J. Yang, S. Mi, et al., Tumour necrosis factoralpha G-308A polymorphism and risk of coronary heart disease and myocardial infarction: A case-control study and meta-analysis. Journal of Cardiovascular Disease, 2012, 3(2): 84-90.

[17] L. Ghazouani, TNF- $\alpha-308$ GNA and IL-6-174GNC polymorphisms in Tunisian patients with coronary artery disease. Clinical Biochemistry, 2010, 43:1085-1089.

[18] R. Banerjee, V. Parihar, Association between inflammatory gene polymorphisms and coronary artery disease in an Indian population. Journal of Thrombosis and Thrombolysis, 2009, 27: 88-94.

[19] N. Somayyeh, M. Zahra, A. Soheil, et al., Evaluation of relationship between single-nucleotide polymorphism in TNF-gene promoter and susceptibility to atherosclerosis in Fatemeh Zahra Hospital. Research in Molecular Medicine (RMM), 2018, 6(1): 41-53.

[20] J. Vendrell, C. Gutierrez, A. Zamora, et al., A polymorphism in the promoter of the tumor necrosis factor-alpha gene (-308) is associated with coronary heart disease in type 2 diabetic patients. Atherosclerosis, 2003, 167: 257-264.

[21] C. Szalai, J. Duba, J. Kramer, et al., Association of polymorphisms and allelic combinations in the tumour necrosis factor-alpha complement MHC region with coronary artery disease. Journal of Medical Genetics, 2002, 39(1): 46-51.

[22] S. Hussain, TNF-alpha-308G $>$ A polymorphism and the risk of familial CAD in a Pakistani population. Human Immunology, 2015, 76: 13-18.

[23] M.S. Afzal, Influence of IL-10 polymorphism on the development of coronary artery disease in Pakistan. Asian Biomedicine, 2012, 6: 159-165.

[24] M. Zahra, S.B. Aref, J. Eisa, et al., Association assessment of Interleukine-10 gene polymorphism and its expression status with susceptibility to coronary artery disease in Iran. The Egyptian Journal of Medical Human Genetics, 2018, 19: 31-35.

[25] M.J. Bown, G.M. Lloyd, R.M. Sandford, et al., The interleukin-10-1082 'A' allele and abdominal aortic aneurysms. Journal of Vascular Surgery, 2007, 46: 687.

[26] J. Chen, Z.Q. Sun, J.H. Xia, et al., Relationship between polymorphism of IL-10-1082 gene and coronary atherosclerotic heart diseases. Acta Medicinae Universitatis Science Technologiae Huazhong, 2007, 36: 614-616.

[27] S. Ben-Hadj-Khalifa, L. Ghazouani, N. Abboud, et al., Functional interleukin-10 promoter variants in coronary artery disease patients in Tunisia. European Cytokine Network, 2010, 21: 136-141.

[28] E. Karaca, M. Kayıkçıoglu, H. Onay, et al., The effect of interleukin-10 gene promoter polymorphisms on earlyonset coronary artery disease. Anadolu Kardiyoloji Dergisi, 2011, 11: 285-289.

[29] A. Manginas, A. Tsiavou, A. Chaidaroglou, et al., Inflammatory cytokine gene variants in coronary artery disease patients in Greece. Coronary Artery Disease, 2008, 19: 575-582.

Copyright $₫$ Abbas Ali Menshed, Hasan R. Khudhur, and Luma Hakem Ali. This is an open-access article distributed under the terms of the Creative Commons Attribution License, which permits unrestricted use, distribution, and reproduction in any medium, provided the original author and source are credited. 